\title{
POLE ODPOWIEDZIALNOŚCI I DRAMAT WINY W MYŚLI KSIĘDZA JÓZEFA TISCHNERA I KARDYNALA STEFANA WYSZYŃSKIEGO. O DUSZPASTERSKIM ROZWINIECIU FILOZOFII ODPOWIEDZIALNOŚCI
}

DOI: http://dx.doi.org/10.12775/SPLP.2021.006

\section{Streszczenie}

Artykuł ukazuje zbieżność poglądów na temat odpowiedzialności, jakie znaleźć można w filozoficznych tekstach księdza Józefa Tischnera i mających charakter duszpasterskich tekstach kardynała Stefana Wyszyńskiego. Myśl Wyszyńskiego można widzieć jako duszpasterskie dookreślenie i rozwinięcie filozoficznych poglądów Tischnera na temat odpowiedzialności. W artykule przedstawiam Tischnerowskie myślenie o ,polu odpowiedzialności” i pokazuję, w jaki sposób to samo zagadnienie pojawia się w wybranych wypowiedziach kardynała Wyszyńskiego. Następnie omawiam „dramatyczny” wątek Tischnerowskiej filozofii odpowiedzialności, którego elementem centralnym jest zagadnienie winy, i na wybranych tekstach kardynała Wyszyńskiego pokazuję, w jaki sposób wątek ten jest obecny także w jego myśli. Na koniec ukazuję wartość duszpasterskiego rozwinięcia filozoficznej analizy zagadnień związanych z odpowiedzialnością.

Słowa kluczowe: Józef Tischner, Stefan Wyszyński, odpowiedzialność, agatologia, filozofia dramatu 


\title{
RESPONSIBILITY AND GUILT IN JOZEF TISCHNER'S AND STEFAN WYSZYNSKI'S THOUGHT. THE PASTORAL ASPECT OF THE PHILOSOPHY OF RESPONSIBILITY
}

\begin{abstract}
The paper shows the convergence of views on responsibility that can be found in the philosophical texts of Fr. Józef Tischner and the pastoral texts of Cardinal Stefan Wyszyński. Wyszyński's thought can be seen as a pastoral clarification and development of Tischner's philosophical views on responsibility. In the paper, I present Tischner's thought on the 'field of responsibility' and show how the same issue appears in selected statements of Cardinal Wyszynski. Next, I discuss the "dramatic" theme of Tischner's philosophy of responsibility, the central element of which is the question of guilt, and on the basis of selected texts by Cardinal Wyszyński, I show how this theme is also present in his thought. Finally, I show the value of a pastoral development of the philosophical analysis of issues related to responsibility.
\end{abstract}

Keywords: Józef Tischner, Stefan Wyszyński, responsibility, agatology, The philosphy of drama

Zagadnienie odpowiedzialności jest jednym z najważniejszych problemów zarówno filozofii, jak i teologii, zwłaszcza w jej wymiarze duszpasterskim. Jest tak nie tylko dlatego, że podejmując problem odpowiedzialności, musimy poruszyć wiele istotnych zagadnień dotyczących Boga, człowieka i świata. Jest tak również dlatego, że zagadnienie to ma ogromne znaczenie praktyczne. Pytanie o odpowiedzialność, to pytanie o prawa i obowiązki, jakie ma człowiek w stosunku do siebie samego, innych ludzi i Boga, a pośrednio także do wszystkich bytów, które do świata należą.

W niniejszym tekście zamierzam pójść śladem dwóch myślicieli, którzy podejmowali namysł nad problemem odpowiedzialności: księdza Józefa Tischnera i kardynała Stefana Wyszyńskiego. Traktuję ich w pierwszym rzędzie właśnie jako myślicieli, którzy nad problemem odpowiedzialności podejmowali głęboką refleksję. Niemniej istotną kwestią jest jednak praktyczne nachylenie myśli ich obu. W przypadku kardynała Wyszyńskiego sprawa jest dość prosta: o odpowiedzialności mówił i myślał w kontekście swojej posługi kierowania Kościołem w Polsce $\mathrm{w}$ trudnych czasach komunizmu. Zagadnienie to w postaci cennych wskazówek dla wiernych, pojawiało się często w jego homiliach i konferencjach. W przypadku księdza Józefa Tischnera sprawa jest nieco bardziej skomplikowana. Z jednej strony prowadził on namysł nad odpowiedzialnością przede wszystkim na pozio- 
mie czysto teoretycznym, nawiązując przy tym do wielkich mistrzów filozofii odpowiedzialności, takich jak Ingarden czy Levinas. $Z$ drugiej strony jego myślenie nigdy nie było „czysto” teoretyczne - w tle tego myślenia zawsze znajdował się drugi człowiek i Bóg, zawsze był ludzki dramat, który ostatecznie okazuje się być dramatem z Bogiem. W tle jego myśli zawsze była jakaś „,bieda”, na którą myślenie musi odpowiedzieć. Odniesienie do ludzkich spraw, do spraw konkretnych ludzi, łączy obydwu myślicieli. Jest także powodem, dla którego warto szukać tego, co łączy proponowane przez nich ujęcia zagadnienia odpowiedzialności.

Sądzę, że punkty wspólne obydwu ujęć stanowią przynajmniej dwie kwestie. Pierwszą jest zagadnienie „pola odpowiedzialności”, drugą zaś „wątek dramatyczny", którego najistotniejszym elementem jest myślenie o odpowiedzialności jako odpowiedzi na konkretną winę. Na różne sposoby, przy użyciu charakterystycznych dla każdego z tych myślicieli sposobów wyrażania się i obrazowania, obydwa te elementy namysłu nad odpowiedzialnością pojawiają się w tekstach zarówno księdza Józefa Tischnera, jak i kardynała Stefana Wyszyńskiego. Ukazując te dwa wątki, zwrócę uwagę na chronologię ich wypowiedzi. Myśl Tischnera o odpowiedzialności rozwijała się od pojmowania jej w kategoriach zakorzenionych w filozofii Ingardena po przyswojenie wątków pochodzących z prac Levinasa. Autorzy opracowań na temat Tischnerowskiej filozofii odpowiedzialności podkreślają, że jego pojmowanie odpowiedzialności ewoluowało od ujęcia ,aksjologicznego” do „agatologicznego". W przypadku kardynała Wyszyńskiego ten kontekst czasowy jest być może jeszcze ważniejszy, ponieważ wiąże się z umiejscowieniem poszczególnych wypowiedzi na temat odpowiedzialności w kontekście konkretnych wydarzeń, jakie miały miejsce w powojennej historii Polski i wyzwań, przed jakimi stał kierowany przezeń Kościół. Moim zamiarem nie jest jednak drobiazgowa analiza kontekstów poszczególnych ujęć odpowiedzialności, jakie zostawili nam Tischner i Wyszyński. Nie zamierzam także badać wzajemnego wpływu obydwu myślicieli. Chodzi mi przede wszystkim po pierwsze o ukazanie zbieżności myślenia na temat odpowiedzialności pomiędzy tymi dwoma nauczycielami polskiego katolicyzmu, a po drugie znalezienie odpowiedzi na pytanie, dlaczego konieczne jest duszpasterskie dookreślanie filozoficznych postulatów

\footnotetext{
Na temat Tischnerowskiego pojmowania odpowiedzialności zob. J. Jagiełł, Ingarden - Tischner. Od ontologii do agatologii odpowiedzialności, w: Dziedzictwo etyki wspótczesnej. Aksjologia i etyka Romana Ingardena i jego uczniów. Studia i rozprawy, red. P. Duchliński, Wydawnictwo WAM, Kraków 2015, s. 241-268; S. Przybyło, Odpowiedzialność a wolność w myśli ks. Józefa Tischnera, w: Społeczeństwo odpowiedzialne? O aspektach odpowiedzialności w życiu społecznym jednostek, red. K. Cikała, W. B. Zieliński, Uniwersytet Papieski Jana Pawła II w Krakowie, Wydawnictwo Naukowe, Kraków 2015, s. 7-17; D. Wajsprych, Pedagogia agatologiczna. Studium hermeneutyczno-krytyczne projektu etycznego Józefa Tischnera, Wydawnictwo Naukowe Uniwersytetu Mikołaja Kopernika, Toruń-Olsztyn 2011.
} 
wynikających z namysłu nad odpowiedzialnością. Przedstawię krótko Tischnerowskie myślenie o ,polu odpowiedzialności” i pokażę, w jaki sposób to samo zagadnienie pojawia się w wybranych wypowiedziach kardynała Wyszyńskiego. Następnie omówię „dramatyczny” wątek Tischnerowskiej filozofii odpowiedzialności i na wybranych tekstach kardynała Wyszyńskiego pokażę, w jaki sposób wątek ten jest obecny także w jego myśli. Na koniec postaram się ukazać wartość duszpasterskiego rozwinięcia filozoficznej analizy zagadnień związanych z odpowiedzialnością.

\section{POLE ODPOWIEDZIALNOŚCI}

Wskazując na warunki powstania w człowieku poczucia odpowiedzialności, Tischner wymienia dobrą wolę, zmysł moralny oraz sumienie. Zaznacza jednak, że „do tego, by poczucie odpowiedzialności rozwinęło się, człowiek musi mieć świadomość (przekonanie), że w konkretnej sytuacji, w jakiej się znalazł, nie tylko wiedział, co robić należy, lecz rzeczywiście mógł coś zrobić”’2. Tischner podkreśla, że odpowiedzialność człowieka sięga tylko tak daleko, jak daleko rozpościerają się granice możliwości skutecznego działania. Człowiek nie powinien zatem myśleć o odpowiedzialności „w ogóle”. Odpowiedzialność jest zawsze umiejscowiona w bardzo konkretnej sytuacji. Ważne jest jednak, by tę sytuację właściwie zrozumieć.

Poczucie odpowiedzialności może się zrodzić tam, gdzie spełnione są warunki o charakterze subiektywnym i obiektywnym. Wśród subiektywnych najważniejsze jest przekonanie człowieka, że jest rzeczywistym sprawcą aktu moralnego i jego skutków. Co więcej - podkreśla Tischner - „,człowiek musi odkryć co dobre, co lepsze, co najlepsze, musi zobaczyć siebie w relacji do odkrytego dobra i zła, musi nadto mieć świadomość własnej siły, własnej zdatności do podjęcia owego aktu, musi wreszcie domyślić się, co zrobić, kiedy zrobić, jakich środków użyć do obranego celu" . A zatem wśród warunków subiektywnych mieszczą się także zdolność do wartościowania, zdolność do widzenia własnych działań w perspektywie aksjologicznej, świadomość własnej sprawczości i zdolność do właściwego zorientowania się w sytuacji, innymi słowy - umiejętność dobrania właściwych środków do celu, który zamierza się osiągnąć.

Szczególnie istotne wydaje się pośród tych warunków zwrócenie uwagi na wartościowanie. Tischner zaznacza, że człowiek musi „odkryć” to, co dobre, lepsze i najlepsze. „Odkrycie” zakłada jednak uprzednie obiektywne istnienie tego

2 J. Tischner, Etyka wartości i nadziei, w: J. Tischner, J. A. Kłoczowski, Wobec wartości, W drodze, Poznań 2001, s. 71.

3 Tamże, s. 72. 
aksjologicznego porządku. Człowiek odkrywa, nie zaś wymyśla czy ustala porządek tego, co dobre, lepsze i najlepsze. Istnienie niezależnego od człowieka porządku wartości to pierwszy obiektywny warunek odpowiedzialności. Drugi z warunków obiektywnych wiąże się z tym, że określone środki w najlepszy sposób prowadzą do zrealizowania określonych celów. Relacja „środek-cel”, nawet jeśli wiąże się z pomysłowością człowieka, który znajduje się w określonej sytuacji, nie realizuje się jednak w próżni, lecz w obiektywnym porządku, w którym cele i środki prowadzące do ich zrealizowania są ze sobą ściśle połączone. Trzecim, bez wątpienia najważniejszym obiektywnym warunkiem, jest to, kim jest człowiek. Człowiek może być odpowiedzialny tylko wówczas, jeśli jest istotą zdolną do odpowiedzialności. Jeśli mielibyśmy do czynienia z istotą zniewoloną, bezmyślną bądź pozbawioną siły do działania, obiektywne warunki odpowiedzialności nie mogłyby być zrealizowane. Tymczasem mamy do czynienia z istotą, której status ontologiczny umożliwia i pociąga odpowiedzialność. Kwestią najistotniejszą w kontekście problemu odpowiedzialności, jest prawda o tym, kim jest człowiek. Ujęcia redukcjonistyczne, pozbawiające człowieka wymienionych wyżej cech i zdolności, wykluczają mówienie o odpowiedzialności.

Spełnienie wyżej wymienionych warunków prowadzi do wyznaczenia ,pola odpowiedzialności”. Pojęcie „,pola”, jak zaznacza Tischner, wiąże się z podkreśleniem cielesnego aspektu istoty ludzkiej. To swoiste ,wcielenie odpowiedzialności” sprawia, że jest ona zawsze konkretna, choć zarazem ograniczona. ,'Pole odpowiedzialności' rozpościera się wokół każdego człowieka i obejmuje tę 'przestrzeń' jego życia, w której człowiek w pojedynkę lub wespół z innymi może skutecznie chcieć dobra"4 - konstatuje Tischner. Wszystko to sprawia, dodaje, że odpowiedzialność realizuje się w konkretnej, zmiennej, często niepowtarzalnej sytuacji i należy brać pod uwagę zmienne siły zaangażowanego. Brak uwzględnienia tych warunków prowadzi do wynaturzeń pojmowania odpowiedzialności. Jedne z tych wynaturzeń prowadzą do dyspensowania się od odpowiedzialności w związku z nieumiejętnością wystarczająco szerokiego widzenia ,pola odpowiedzialności", inne do brania na siebie odpowiedzialności zbyt wielkiej, niemożliwej do zrealizowania. Można powiedzieć, że według Tischnera zadaniem człowieka jest zrealizowanie odpowiedzialności na jego miarę - miarę wyznaczoną mu tu i teraz. Zagadnienie odpowiedzialności, a przede wszystkim problem wskazania właściwego jej ,pola”, to niezwykle trudne zadanie. Tischner zaznacza, że zrealizowanie tego zadania „wymaga rozumu, cierpliwości, roztropności, których ludziom najczęściej brak”. Dodaje, że sprawa właściwego wyznaczenia „pola odpowiedzialności” jest bardzo ważną sprawą ludzkiego życia i zachęca do „częstej refleksji krytycznej" nad tym zagadnieniem5.

\footnotetext{
4 Tamże.

5 Por. tamże, s. 75.
} 
Refleksję taką podejmował kardynał Wyszyński. Ukażę ją, wykorzystując do tego Tischnerowski opis ,pola odpowiedzialności” i biorąc pod uwagę warunki zaistnienia odpowiedzialności, o których koniecznym zachodzeniu Tischner wspominał. Z tego, iż nad problemami związanymi z odpowiedzialnością należy myśleć, Wyszyński doskonale zdawał sobie sprawę. Podkreślał, że namysł ten jest konieczny tym bardziej, im większa jest świadomość odpowiedzialności. W roku 1980 mówił, iż w tym właśnie czasie naród polski dochodzi do świadomości swojej odpowiedzialności, a więc do rozeznania swoich praw i obowiązków w ojczyźnie. Konstatował wówczas: „To wszystko, jak wiemy, wymaga rozwagi, roztropności, ducha pokoju i pracy, bez którego nie ma właściwego rozwiązania sytuacji pomimo najsłuszniejszych racji, jakie moglibyśmy przytoczyć"”.

Namysł nad odpowiedzialnością prowadzić ma wedle Wyszyńskiego do znalezienia odpowiedniego pola, na którym ma się ona realizować. W jednym ze swoich tekstów pisał: „Zdawałoby się, że nie jest trudne znaleźć pole dla naszych czynów płynących z miłości. A jednak często ludzie nie dostrzegają sposobności czynienia wszystkiego w duchu sprawiedliwości i miłości. Pomyślmy, jak nieraz samolubnie układamy nasze życie. Żyjemy tylko dla siebie, jakby poza nami nikt nie istniał. [...] Pierwszym wymaganiem miłości i sprawiedliwości będzie uznać i uszanować prawo drugiego człowieka do jego życia, mienia, rozumu, woli i serca, do jego przekonań, godziwych dążeń i pragnień. Za tym pójdzie gotowość do pomagania bliźnim w miarę naszych możliwości, aby mogli korzystać ze swych praw ludzkich, rodzinnych i społecznych; aby zdołali osiągnąć swe godziwe dążenia i wypełnić ciążące na nich obowiązki" wprost określenie ,pole odpowiedzialności”. Mowa jest o ,polu dla naszych czynów płynących z miłości”. Dookreślenia, które odnajdujemy w kolejnych zdaniach cytowanego tekstu, a zwłaszcza zwrócenie uwagi na powinności, które wiążą się ze sprawiedliwością i miłością, pozwalają nam zinterpretować tę wypowiedź jako próbę wyznaczenia „pola odpowiedzialności”. Tym bardziej, że w dalszej części tego tekstu czytamy o pracy jako wspaniałym polu, którym daje o sobie znać społeczny charakter człowieka. Kardynał Wyszyński zwraca także uwagę na sposobności do okazywania miłości, jakie pojawiają się w pracy zawodowej, fabrycznej czy urzędniczej. Dodaje przy tym, iż nikomu nie wolno dyspensować się od

6 S. Wyszyński, Odpowiedzialność - Obowiazki - Prawa w życiu Narodu. Kazanie wygłoszone podczas sumy w uroczystość Matki Bożej Częstochowskiej, Jasna Góra - 26 VIII 1980 r., w: Nauczanie społeczne Kardynała Stefana Wyszyńskiego (wybór tekstów), Wydział Inicjatyw Społeczno-Katolickich Stowarzyszenia PAX, Warszawa 1983, s. 142.

7 Tenże, Na siódmy rok Wielkiej Nowenny, w: Listy Pasterskie Prymasa Polski 1946-1974, Editions du Dialogue, Paris 1975, s. 426-427. Warto zaznaczyć, że pojęcie ,pola” (przy czym mowa jest wprost o ,polu odpowiedzialności”) pojawiło się także w tytule jednego z dzieł kardynała Karola Wojtyły. Napisane zostało ono już w latach 70. XX wieku, lecz wydane zostało dopiero w roku 1991. Zob. K. Wojtyła, Człowiek w polu odpowiedzialności, Instytut Jana Pawła II KUL, RzymLublin 1991. 
tych obowiązków, ponieważ ich podjęcie ma wpływ na całą rodzinę domową, narodową czy też na pracującą wspólnotę. Zdaniem Wyszyńskiego pole dla uczynków płynących z miłości jest bardzo szerokie. Pyta: „Któż zdoła wyliczyć tysiące sposobności, gdzie duch chrześcijański przynagla nas, aby wiara nasza żyła z dobrych uczynków?”. I apeluje: „Bądźmy chrześcijanami nie tylko w skrytości serca, przy zamkniętych drzwiach domu, w kruchcie kościelnej - ale też na ulicy, w biurze, $w$ warsztacie fabrycznym, na roli i w wielu innych miejscach, gdzie żyje i pracuje człowiek, dziecko Boże, Chrystusowy brat, siostra i matka"8.

Podejmowanie odpowiedzialności w tak szerokim wymiarze jest konieczne jako element kształtowania się człowieka. Dojrzewa on poprzez prawa i obowiązki, które wzajemnie się krzyżują. Przez połączenie praw i obowiązków, tak indywidualnych, jak i wspólnych, człowiek może stać się pełną osobowością i rozwinąć swoje człowieczeństwo i kulturę osobistą . Aby jednak możliwe było podjęcie odpowiedzialności, muszą zostać spełnione określone warunki. Najważniejszym z nich jest poczucie godności. W konferencji poświęconej Konstytucji duszpasterskiej II Soboru Watykańskiego Wyszyński przywoływał następujące słowa: „człowiek z trudem dochodzi do takiego poczucia odpowiedzialności, jeśli warunki życia nie pozwalają mu uświadomić sobie swojej własnej godności i jeśli nie żyje zgodnie ze swym powołaniem, poświęcając się służbie Bogu i bliźnim"10.

Poczucie godności musi jednak zostać oparte na wystarczająco mocnym fundamencie. Kluczem do niej jest właściwe pojmowanie człowieka. Wyszyński pisał: „Wydaje mi się, że mimo upływu tylu wieków i epok, ciągle jeszcze nie znaleziono takiej miary, jaką można by oceniać człowieka. Nie chodzi nam w tej chwili o walkę społeczną, ekonomiczną, polityczną czy światopoglądową, lecz o właściwe pojmowanie człowieka. Takie, jakie ma Ojciec człowieka - Bóg nasz i Stwórca, który sam ze swej Osobowości, Istności, tchnął w nas tchnienie życia [...]"11. Zdaniem Wyszyńskiego jedynym wystarczającym zabezpieczeniem poczucia godności jest chrześcijańskie pojmowanie człowieka. Podkreślał: „Trzeba sobie zdać sprawę z wysokiej wartości osoby ludzkiej, a także z wartości każdej chwili życia. Z uporem powtarzamy ludowi Bożemu wieku XX, skąd się wywodzi człowiek. Czynimy to nie dla podtrzymywania fabuły, jak się komuś może zdawać, ale dla stwierdzenia, że wszyscy musimy koniecznie pamiętać o wysokiej godno-

\footnotetext{
Tamże.
}

9 Por. S. Wyszyński, Jakiej chcecie Polski? Do młodzieży akademickiej na zakończenie rekolekcji 22 marca 1972, w: tenże, Nie chciejcie łatwego życia, Wydawnictwo UKSW, Warszawa 2007, s. 124.

10 Tenże, Wspólnota ludzka. Konferencja na temat Konstytucji duszpasterskiej o Kościele w świecie wspótczesnym. 4 marca 1968, w: S. Wyszyński, Nie chciejcie tatwego życia, dz. cyt., s. 399.

11 Tenże, Bogami jesteście. Do młodzieży akademickiej na zakończenie rekolekcji 17 marca 1973, w: tenże, Nie chciejcie łatwego życia, dz. cyt., s. 135. 
ści człowieka”'12. Pod koniec życia Wyszyński raz jeszcze przypominał: „Gdy więc przyglądamy się problemom nękającym współczesnych ludzi, musimy pamiętać o jednym: aby zdobyć zaufanie i pokój należy skończyć z resztkami programów głoszonych przez 'pożeraczy Boga'. Niestety, ciągle jeszcze dochodzą one do głosu i w naszej Ojczyźnie. [...] Wiemy przecież, że religijny system moralny jest podstawowym warunkiem ładu osobistego i społecznego - zwłaszcza obowiązkowości - dlatego powinien być uznany za sprzymierzeńca naszego codziennego życia. [...] Doświadczenie ostatnich dni poucza nas, że najważniejszym czynnikiem w ekonomii narodowej, mającym moc uleczenia jej, jest etyka, moralność chrześcijańska. Ona jest głównym czynnikiem - i to rozumieją wszyscy ludzie w Polsce, wszyscy - podkreślam. Bez wprowadzenia zasad moralności chrześcijańskiej, a więc obowiązkowości, sumienności i ładu współżycia do naszej codzienności życiowej, nie da się uleczyć porządku społecznego i ekonomicznego w naszej Ojczyźnie i świecie. [...] pierwszą wartością, pierwszą mocą konieczną dla zaprowadzenia harmonii życia i współżycia w świecie i w naszej Ojczyźnie, jest Bóg uznany i umiłowany"13. Zdaniem Wyszyńskiego, odkrywając prawdę na temat swojej godności - prawdę, jaka została objawiona w Ewangelii - ludzie zyskują nie tylko zestaw wymogów, jakie należy spełnić w relacji do Boga i innych ludzi, lecz przede wszystkim najgłębszą podstawę do patrzenia na samych siebie jako istoty zdolnej do odpowiedzialności.

Aby pogłębić w słuchaczach świadomość ich godności, Wyszyński często przytaczał słowa Jezusa, będące nawiązaniem do Psalmu 82: „Bogami jesteście”. Mówił: „Kościół zdecydowanie i nieustępliwie, całą mocą swej żywej wiary, przekonuje ludzkość o wysokiej godności osoby ludzkiej i o jej Bożym pochodzeniu. Chrystus, który też musiał toczyć spory ze swoim środowiskiem na temat godności człowieka, przypominał: Czyż nie napisano w waszym Prawie: Ja rzekłem: Bogami jesteście! Jeżeli [Pismo] nazywa Bogami tych, do których skierowano słowo Boże - a Pisma nie można odrzucić - to jakżeż wy o Tym, którego Ojciec poświęcił i posłał na świat, mówicie: Bluźnisz, dlatego że powiedziałem: Jestem Synem Bożym?"'14. To właśnie ze świadomości Bożego synostwa płynie zobowiązanie do tego, by człowiek czynił sobie ziemię poddaną. Jest to jednocześnie zobowiązanie do tego, by nie stawać się niewolnikiem ziemi, materii ani cywilizacji materialnej bądź filozofii materialistycznej. Filozofia taka skrajnie

12 Tenże, Wasza godność i czas cenniejsze niż złoto. Inauguracja roku akademickiego 4 października 1970, w: tenże, Nie chciejcie łatwego życia, dz. cyt., s. 114.

13 Tenże, Harmonia Bożo-ludzka w Polsce. II Kazanie wygłoszone w Bazylice Archikatedralnej Św. Jana Chrzciciela w Warszawie - 6 I 1980 r., w: Nauczanie społeczne Kardynała Stefana Wyszyńskiego (wybór tekstów), Wydział Inicjatyw Społeczno-Katolickich Stowarzyszenia PAX, Warszawa 1983, s. 100-101.

14 Tenże, Wasza godność i czas cenniejsze niż złoto. Inauguracja roku akademickiego 4 października 1970, w: tenże, Nie chciejcie łatwego życia, dz. cyt., s. 114. 
redukuje prawdę o człowieku, uniemożliwiając mu patrzenie na siebie jako na istotę zdolną do odpowiedzialności. Pisał Wyszyński: „Bo to wszystko jest za mało. To jest niewystarczająca strawa dla odżywienia człowieka, który ma na sobie stygmaty pochodzenia od Boga; o którym można mówić: Bogiem jesteś, bo masz aspiracje, które są usprawiedliwione, aspiracje władania nad porządkiem rzeczy, aby nie zostać jego niewolnikiem"15.

Nie tylko pochodzenie człowieka od Boga stanowić miało grunt dla poczucia godności, lecz także przekonanie o tym, iż Bóg zaprosił ludzi do udziału w dziele zbawiania świata. Godność wynikać miała zatem nie tylko z tego, „kim” jesteśmy jako ludzie, lecz także „po co” jesteśmy, do czego zmierzać ma ludzkie życie. Wyszyński pisał, iż Bóg oczekuje od człowieka pomocy w dziele zbawiania świata, nieustannie „ogląda się za człowiekiem”, liczy na niego ${ }^{16}$.

Osadzenie myślenia o ludzkiej i chrześcijańskiej godności na najbardziej fundamentalnej prawdzie o pochodzeniu człowieka od Boga, o Bożym synostwie, zyskiwały w tekstach Wyszyńskiego dalszą konkretyzację. Warto zaznaczyć, że poszukując adekwatnego gruntu dla poczucia odpowiedzialności wśród ludzi swoich czasów, Wyszyński bardzo mocno podkreślał chrześcijańskie korzenie narodu polskiego i jego chrześcijańskie dziedzictwo, a także istotną rolę religii w byciu człowiekiem. Mówiąc o prawach i obowiązkach rodziców katolickich w wychowaniu dzieci, przypominał im, iż po pierwsze „są ludźmi”, a istotnym elementem wychowania ludzkiego jest wychowanie religijne. Przypominał im także, iż są ,,istotami rozumnymi”, a to daje im prawo do wychowywania dzieci wedle najlepszego rozumienia. Bycie „istotami wolnymi” wiązać się miało z kolei z prawem do wolności oddziaływania na własne dzieci zgodnie z rozumnym porządkiem rzeczy, zaś bycie ,istotami miłującymi” miało być podstawą prawa do wolności przekazywania dzieciom tego, co samemu się miłuje i do dbania o to, by inni czynili tak samo w imieniu rodziców. Inne dookreślenia tego, kim są katoliccy rodzice, wiązały się z faktem bycia „Bożymi dziećmi” i „rodzicami Bożych dzieci”, co wiązało się z prawem i obowiązkiem wychowywania dzieci zgodnie z doczesnym i wiecznym celem. „Bycie rodzicami katolickimi” z kolei wiązać się miało z prawem i obowiązkiem wychowywania dzieci zgodnie z nauką Kościoła. Wedle Wyszyńskiego element tożsamości rodziców miało stanowić także ich bycie „dziećmi narodu katolickiego”, „obywatelami państwa” i „członkami rodziny narodów". To pierwsze miało wiązać się ze świadomością, iż konieczne jest wychowywanie sumień, które jest warunkiem dobrego funkcjonowania międzyludzkich relacji, to drugie było przypomnieniem prawdy, iż warunkiem życia zgodnego z prawami obywatelskimi jest oparcie życia społecznego na prawie Bożym, a sprawiedliwości społecznej na Bożym pojmowaniu sprawiedli-

15 Tamże, s. 115.

16 Por. tenże, Wiara i odpowiedzialność, Wydawcnictwo Sumus, Soli Deo, Zielonka 2021, s. 24. 
wości, to trzecie zaś prowadzić miało do odkrycia, iż powszechna miłość i pokój nie będą możliwe bez miłości ku „Ojcu wszystkich narodów” ${ }^{17}$. Ten bardzo szeroki i precyzyjny opis pokazuje, jak istotną kwestią było, zdaniem Wyszyńskiego, dookreślenie tożsamości człowieka, który ma podjąć odpowiedzialność za różne sprawy własnego życia i życia innych ludzi. Nie wystarczy posługiwać się ogólnymi określeniami. $Z$ tych ogólnych i fundamentalnych określeń należy wyprowadzić bardzo szczegółowy opis, obejmujący wszystkie wymiary życia i międzyludzkich relacji.

Na tak mocnym gruncie możliwe jest osadzenie poczucia odpowiedzialności. Istotną kwestią jest jednak to, iż odpowiedzialność ta przybierać powinna różne formy w zależności od okoliczności dziejowych, w jakich ma się realizować. Najpierw miała to być odpowiedzialność za zwykłe, codzienne życie. Wyszyński apelował do wspaniałych cech, które ujawniły się w Polakach w czasie II wojny światowej. Zwracał jednak uwagę, że w czasie powojennym muszą się one realizować w innym wymiarze i w radykalnie odmienny sposób. Pisał: „Po ulicach naszych miast i wiosek chodzi dziś wielu ludzi, których czyny były bohaterskie, przeżycia niezwykłe, cnoty w obliczu wroga zadziwiające. Ludzi, którzy załamali się w wierności Ojczyźnie, było niewielu. Ale niestety! Od dawna mówiono o nas, że jesteśmy wielcy w cierpieniu, mali - w codziennym trudzie życiowym. Bohaterscy zwycięzcy z pierwszej linii bojowej, w brawurowym ataku rozśpiewani, butelkami benzyny zdobywający tanki, padają dziś ofiarą [...] butelki wódki, ulicznej pokusy, lenistwa i próżniactwa, pospolitego warcholstwa i wszystkich pożądliwości oczu, ciała, pychy żywota, wszystkich głównych grzechów, wołających niekiedy o pomstę do Boga" ${ }^{18}$. W tekstach Wyszyńskiego, począwszy od tych powojennych aż po teksty pisane w latach 70 . i 80 . XX wieku, widać wyraźnie zakreślanie coraz to nowych ,pól odpowiedzialności”, których powstawanie jest odpowiedzią na zmieniające się warunki życia. W roku 1947 pisał: „Macie oprzeć się fali powojennego zdziczenia, pełnego przekleństw rozpijaczenia, nieładu, pogardy dla porządku i przyzwoitości. Wiedzcie, że to nic nie ma wspólnego ze zdrowym postępem, gdyż rzetelny postęp społeczny nie spycha ludzi do rzędu pariasów, ale podnosi ich na wyższy poziom osobistego stylu i współżycia z ludźmi"'19. Odpowiedzialność polegać więc miała wówczas na podjęciu próby wykorzenienia szczególnie dotkliwych wad, które uniemożliwiają życie społeczne. W ślad za wypełnieniem wad iść jednak miało działanie o charakterze pozytywnym, twórczym. Już w roku 1948 Wyszyński pisał: „Mamy wzmacniać troskę o chorych członków rodziny, opiekę nad słabowitymi dziećmi, dotkniętymi wieloma plagami

17 Por. tenże, Do rodziców katolickich w sprawie religijnego wychowania dzieci i młodzieży, w: Listy Pasterskie Prymasa Polski 1946-1974, dz. cyt., s. 208-209.

18 Tenże, O katolickiej woli życia, w: Listy Pasterskie Prymasa Polski 1946-1974, dz. cyt., s. 59.

19 Tenże, Do szkolnej młodzieży katolickiej z okazji nowego roku szkolnego, w: Listy Pasterskie Prymasa Polski 1946-1974, dz. cyt., s. 76. 
w wyniku warunków bytowania powojennego: gruźlicy, chorób zakaźnych, alkoholizmu, ciasnoty mieszkaniowej, bezdomności itp. Mamy budzić w Narodzie wolę dążenia do zdrowia w rodzinie, do poszanowania daru życia, do podniesienia wrażliwości na maluczkich i słabe niemowlęta" ${ }^{20}$. W tym samym tekście Wyszyński apelował o to, by pomóc rodzinie oraz by poprzez przypomnienie Bożego ustanowienia małżeństwa, jego nadprzyrodzonego charakteru, podnieść rodzinę, a także o to, by przypomnieć wysoką godność kobiety i godność ciała ludzkiego, przywrócić prawa dziecka, uświadomić osobisty i społeczny charakter małżeństwa i uznać jego doniosłość dla narodu i państwa.

Zachęta do pracy nad sobą czasem przyjmowała w tekstach Wyszyńskiego jeszcze bardziej precyzyjny wymiar. Zdarzało się, iż wprost wskazywał zadania osób związane z pełnionymi przez nie w Kościele, państwie i rodzinie rolami. Co więcej, zdania te miały być wypełniane w bardzo konkretnym czasie życia, a nawet w konkretnych dniach danego roku. W Zachęcie do duchowieństwa $i$ wiernych świeckich na Wielki Post w roku 1952 Wyszyński wzywał kapłanów do podjęcia ofiary pracy wielkopostnej, która miała zmierzać do tego, by każda parafia wolna była od grzechu i mogła zostać duchowo odnowiona. Polem ich odpowiedzialności miała być ambona i konfesjonał. Wyrazem odpowiedzialności miały być modlitwa, umartwienie i słowa pokrzepienia dawane ludziom, którzy przychodzą, by nawrócić się z grzechu. Wiernym świeckim z kolei zalecał, aby spokojnie, w duchu pokuty, znosili mękę każdego dnia. Zachęcał ich do wysłuchania nauk rekolekcyjnych, odbycia spowiedzi (przy czym prosił, by nie odkładać jej na później). Apelował, by rodziny dbały o prowadzenie domu po Bożemu, w duchu skupienia i wspólnej modlitwy. Prosił o przywrócenie poczesnego miejsca krzyżowi w domach, o wspólną modlitwę przed krzyżem, a także o to, by na stołach rodzinnych znalazło się miejsce na Pismo Święte, katechizm i mszalik z rachunkiem sumienia. Do młodzieży apelował, by powstrzymywała się od zabaw i skupiła na pracy. Do matek mówił o trosce, by wszyscy członkowie rodziny wzięli udział w rekolekcjach stanowych. Dzieci i młodzież prosił o przekazywanie sobie wiadomości o tym, gdzie odbywają się rekolekcje i o czynny udział w nich. Do mężów i młodzieńców katolickich zaś apelował o to, aby po męsku przystąpili do dzieła odnowy własnych dusz. Mówił: „Umiecie Przyłożyć rękę do pługa i nie oglądacie się wstecz. Umiecie kuć żelazo, póki gorące. Umiecie rozżarzać sztaby do białości. Umiecie znosić i trudzić się w pocie czoła na kawałek chleba. Pokażcie, że umiecie też przeorać dusze własne, że umiecie przekuć własne życie w nowe formy, że umiecie rozpalić duszę do białości! Że umiecie zapracować na Chleb żywota! Wyjdźcie na czoło tych, co z krainy grzechu wracają do Ojca, co przystępują do ołtarza Pańskiego! Mężczyźni katoliccy, nie wleczcie się w ostatnich

20 Tenże, List pasterski na Czwarty Tydzień Miłosierdzia, w: Listy Pasterskie Prymasa Polski 1946-1974, dz. cyt., s. 81. 
szeregach. To Wam nie przystoi! Stańcie się przednią strażą Ducha Bożego!"’21. Wedle słów Wyszyńskiego do podjęcia zadań „na zewnątrz”, zadań wspólnych, przygotować mają ludzi zadania, które każdy z nich podejmuje sam: skupienie wewnętrzne, które możliwe jest dzięki milczeniu pozwalającemu słuchać głosu Boga; post języka w domu, pracy, na ulicy; ,rozważanie sercem” - innymi słowy namysł o charakterze duchowym; czytanie Ewangelii, dokumentów soborowych, słuchanie rozważań wielkopostnych, udział w rekolekcjach. Innymi sposobami indywidualnej pracy nad sobą miały być: odpowiedzialność za słowo - wyzbycie się słów burzących wiarę i zasady moralne; rozwijanie w sobie Bożego sposobu myślenia; wyzbycie się bezpłodnej gadaniny; wierność prawdzie; podjęcie odpowiedzialności za wiarę swoją i innych ludzi, które możliwe jest dzięki pracy nad pogłębieniem swojej wierności obowiązkom katolika, wierności krzyżowi, Ewangelii i Kościołowi; wierności w modlitwie, ofiarności i miłości społecznej. Wyszyński patrzył na te zadania bardzo realistycznie. Zalecał: „Chociaż jednemu człowiekowi powiedzcie coś dobrego o Bogu i Jego Kościele! Chociaż raz dajcie świadectwo prawdzie!". Wezwanie do odpowiedzialności zamykał w celnych i łatwych do zapamiętania hasłach, jak to: „Z ludźmi mówcie o Bogu, głoście Go i wyznawajcie. A z Bogiem rozmawiajcie o ludziach, walcząc na modlitwie o ich wiarę, łaskę i świętość"22.

Można by przytoczyć jeszcze wiele innych, bardzo konkretnych, podpowiedzi związanych z poszukiwaniem właściwego pola odpowiedzialności, jakie dawał kardynał Wyszyński. Wiązały się one tak z życiem rodzinnym (obowiązek szerzenia w rodzinie duchu pokoju i dobra, ducha wzajemnej miłości, wyrozumiałości, pomocy, ofiary i wyrzeczenia się siebie; otwartość na nowe życie; pomoc rodzinom wielodzietnym), jak i wykonywaniem pracy (pamięć o tym, że nikt nie pracuje jedynie dla siebie, ale dla całego narodu, co nakłada na każdego obowiązek sumienności, poszanowania dobra publicznego i środków pracy), tak z budowaniem międzyludzkich relacji (wnoszenie wszędzie pokoju, życzliwego słowa, przyjaznego spojrzenia, walka przeciw grubiańskim i obelżywym słowom, poprawianie obyczaju towarzyskiego przez promowanie odpowiedniego stylu rozrywek, walkę wydaną nietrzeźwości czy marnotrawstwu), jak i z mądrym uczestnictwem w życiu politycznym (konieczność zachowania spokoju i umiaru w politycznych

21 Tenże, Zachęta do duchowieństwa i wiernych na Wielki Post, w: Listy Pasterskie Prymasa Polski 1946-1974, dz. cyt., s. 226.

22 Tenże, List wielkopostny do duchowieństwa i wiernych Archidiecezji gnieźnieńskiej i warszawskiej, w: Listy Pasterskie Prymasa Polski 1946-1974, dz. cyt., s. 616-617. 
sporach) ${ }^{23}$. Każdy ma troszczyć się o to, by jak najlepiej wypełniać choćby najprostsze ,zadania chwili obecnej" ${ }^{24}$.

\section{DRAMAT WINY}

Przyjrzyjmy się teraz drugiemu z wątków pojawiających się w myśli Tischnera i Wyszyńskiego - o odpowiedzialności. Jest to wątek, który określić można jako dramatyczny, ponieważ dotyczy realizowania się odpowiedzialności w przestrzeni międzyludzkiego (i bosko-ludzkiego) dramatu. Kluczem do tego wątku jest zagadnienie winy.

Późne, agatologiczne ujęcie odpowiedzialności w myśli Tischnera wiąże się z podkreślaniem istotnego faktu, że odpowiedzialność powstaje w świecie doświadczeń międzyludzkich, międzyludzkich relacji, dialogu. Tischner zaznacza, że odpowiedzialność rodzi się w spotkaniu z twarzą. ,,Twarz objawia się jako dar horyzontu agatologicznego - horyzontu, w którym dobro i zło przybierają formę dramatu, a dramat zapowiada możliwość tragedii lub zwycięstwa człowieka" tłumaczy Tischner ${ }^{25}$. Przekonuje, że źródłem siły odpowiedzialności, która pozwala właściwie odpowiedzieć na wezwanie płynące z twarzy, jest dobro, które się wydarza i udziela. Dobro zaś nie sytuuje się ani po stronie podmiotu, ani po stronie przedmiotu, lecz jest „między nami”. Gdy człowiek spotyka twarz innego, możliwe jest duchowe zbliżenie, które budzi w człowieku odpowiedzialność. W spotkaniu tym następuje odkrycie ,,biedy”, jaką dźwiga drugi człowiek. Tischner tłumaczy: „Gdyby nie było biedy świata, nie byłoby próśb i nikt by nikogo o nic nie pytał. Każde pytanie, bezpośrednio lub pośrednio, świadczy o jakiejś biedzie"26. Tischner przypomina, że pojęcie to, stanowiące podstawową kategorię dramatyczną, określa „sytuację człowieka, a nawet Boga, w dramacie istnienia”"27.

Zdaniem Tischnera podjęcie odpowiedzialności, polegające na wzięciu na siebie cudzej ,,biedy”, jest dla człowieka wielką szansą. Widać to szczególnie wyraźnie w perspektywie chrześcijańskiej. Kluczem do chrześcijaństwa jest bowiem fakt, że to sam Bóg dotknięty jest, ,biedą” - biedą miłości. Odpowiedzialność za innego jest ostatecznie odpowiedzialnością za Boga. Tischner przypomina:

23 Por. tenże, List pasterski o społecznej krucjacie miłości, w: Listy Pasterskie Prymasa Polski 1946-1974, dz. cyt., s. 551-552.

24 O takich zadaniach pisał kardynał Wyszyński w czasie swojego uwięzienia w Prudniku Śląskim: 28 X 1954, Prudnik Śląski: „Nie trzeba na nikogo się skarżyć, ani też do nikogo mieć żalu, tylko cierpliwie i spokojnie się modlić o to, by Bóg pozwolił wypełnić zadanie chwili obecnej” (tenże, Zapiski więzienne, Editions du Dialogue Paris 1982, s. 113).

25 J. Tischner, Filozofia dramatu, Znak, Kraków 1999, s. 84.

26 Tamże, s. 92.

27 Tamże. 
„Chrześcijańska religia dialogu człowieka i Boga stała się możliwa, ponieważ Bóg sam stał się jak wygnaniec, sierota i wdowa. Religia nie polega już na wzniosłym uczuciu zachwytu, który unosi człowieka ku niebu, ani na racjonalnej spekulacji o najwyższym z bytów, ale na poczuciu odpowiedzialności za odpowiedź, jaką

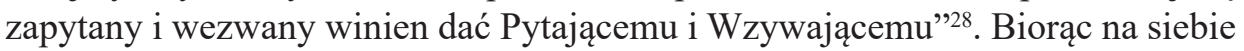
odpowiedzialność za innego, człowiek daje sobie szansę na spotkanie Boga.

Tischner podkreśla także, że z odpowiedzialnością istotnie związana jest wolność. To odpowiedzialność wyznacza wolności pole jej wyboru. Wolność i odpowiedzialność są ze sobą ściśle i nierozerwalnie związane w doświadczeniu dobra, które wydarza się pomiędzy ludźmi. Nie można zatem myśleć o wolności poza kontekstem odpowiedzialności. Bez odpowiedzialności wolność utożsamia się ze swawolą ${ }^{29}$. Wiązanie wolności z odpowiedzialnością nie jest zaprzeczeniem ani nawet osłabieniem wolności. Odpowiedzialność jest sposobem, w jaki wolność się wyraża i realizuje. Ucieczka od odpowiedzialności jest „ucieczką od dobra w stronę swawoli i zła” - pisze Tischner. I dodaje: „To również ucieczka od człowieka - od relacji dialogu, od pytań i roszczeń, od odpowiedzi”"30.

Ucieczka od odpowiedzialności może się także przejawiać w postaci ucieczki od winy. W czasach, o których pisał Tischner, ucieczka od winy dokonywała się w sposób dość szczególny. Po upadku komunizmu - tłumaczył Tischner - trzeba było się uporać $\mathrm{z}$ winą zrodzoną z ,moralności rewolucjonistów”. Moralność ta wyrażała się w podejmowaniu działań, które tłumaczono jako konieczne dla przyszłego szczęścia ludzkości. Po upadku komunizmu wśród byłych rewolucjonistów znaleźli się tacy, którzy potrafili przyjąć na siebie te winę. Większość jednak uciekała od winy. Jedni czynili to poprzez skrajną indywidualizację norm, czyli wmawianie sobie i innym, że w ich konkretnym przypadku zła norma działała w sposób szczególny, a zatem winni nie są, inni przez przyjęcie postawy „bycia sumieniem" - tropienie błędów innych i wytykanie im słabości. Jednakże, jak zauważał Tischner, pierwsza postawa prowadzi do zerwania więzi, wymknięcia się relacji dialogu, druga do postaw demaskatorskich, które są zamaskowaną formą chęci odwetu za zawiedzione nadzieje ${ }^{31}$.

Tischner przypomina, że chrześcijaństwo uczy innego sposobu obchodzenia się z winą. Pisze: „Człowiek lęka się przyznania do win. Dlaczego? W chrześcijaństwie wyznanie win jest pierwszym krokiem ku przebaczeniu. Człowiek, który wyznaje winę, wytrąca miecz z rąk oskarżycieli. Jak można oskarżyć tego, kto już wcześniej sam siebie osądził?" 32 Przyjęcie winy jest sposobem na to, by uchronić się przed rozpaczą - „chorobą na śmierć”. Logika wywodu Tischnera prowadzi

28 Tamże, s. 98.

29 Por. tenże, Gra wokół odpowiedzialności, „Znak” 485, 1995, s. 50.

30 Tamże.

31 Por. tamże, s. 51-54.

32 Tamże, s. 50. 
do tezy, że w warunkach czyjegoś zmagania się z winą, przejawem odpowiedzialności zrodzonej z dobra jest wzięcie na siebie czyjejś winy. Dobro, które przejawia się poprzez twarz człowieka, jest większe i bardziej fundamentalne niż wina, z którą człowiek się zmaga. Więcej - to wina jest istotną „biedą”, jaka obudzić może w człowieku siłę odpowiedzialności. Właściwą postawą wobec takiej „,biedy” nie jest potępianie i skazywanie, lecz wspólne dźwiganie winy.

W tekstach kardynała Wyszyńskiego odnaleźć można wiele wątków korespondujących z Tischnerowskim, agatologicznym ujęciem zagadnienia odpowiedzialności. Wyszyński wskazywał nie tylko na „naturalne” więzi pomiędzy ludźmi, których istnienie mogłoby uzasadniać odpowiedzialność, lecz szukał także teologicznego uzasadnienia dialogicznego rozumienia odpowiedzialności. Pisał: „Tak bardzo związał nas Ojciec niebieski przez wspólne człowieczeństwo. Tak głęboko przeniknął nas wszystkich Chrystus-Głowa przez swoje nadprzyrodzone moce łaski. Czyż wobec tego możemy być sobie obojętni? Czyż możemy żyć obok siebie jakbyśmy się nie widzieli i nie znali, niewrażliwi na siebie wzajemnie, na nasze dole i niedole? Przecież sami nie jesteśmy w stanie dać sobie istnienia ani przygotować się do życia i wypełnić jego zadań. Nie jest rzeczą możliwą wypełnić wspólne zadania rodziny, ułożyć współżycie w Narodzie, w pracy zawodowej, w dziejowym bycie społecznym bez wzajemnej woli pomocy i miłości społecznej. Nasze obowiązki wobec braci płyną ze wspólnoty pochodzenia od Ojca niebieskiego, ze współżycia w nadprzyrodzonym organizmie Kościoła - Mistycznego Ciała Chrystusa" ${ }^{33}$. Wyszyński podkreślał także, iż odpowiedzialność jest istotnie związana z wolnością. Jego zdaniem wiązanie to jest do tego stopnia mocne, że najbardziej radykalna forma odpowiedzialności wyraża się przez dobrowolną „niewolę z miłości”. Wyszyński tak pisał o tej niewoli: „Wiąże ona w rodzinie dwoje, aby służyć dzieciom; dzięki niej żołnierz oddaje życie, aby bronić Ojczyzny; ona wkłada w sumienia ludzkie rzetelność powołania i zawodu, by uczciwie wypełniać zadanie dnia; ona też powołuje ludzi na szczyty bohaterstwa" ${ }^{34}$. Niewola ta jest zaprzeczeniem innych rodzajów niewoli człowieka XX wieku, jak choćby niewoli sumień przez narzucanie niewiary, niewoli nienawiści czy niewoli słabości i grzechu ${ }^{35}$. Kardynał Wyszyński nie tylko wzywał do dobrowolnego oddania się w taka niewolę miłości, lecz wielokrotnie ponawiał akt, na mocy którego w niewolę miłości za wolność Kościoła w świecie i Polsce oraz „dla rozszerzania się Królestwa Chrystusowego na ziemi” się oddawał.

Szczególnie interesujący jest jednak sposób, w jaki Wyszyński podejmował zagadnienie winy. Jego zdaniem nie tylko głębokie więzy wynikające z przyna-

33 S. Wyszyński, Na siódmy rok Wielkiej Nowenny, w: Listy Pasterskie Prymasa Polski 1946-1974, dz. cyt., s. 425.

34 Tenże, Wyzwolenie z niewoli nienawiści przez niewole miłości. Do młodzieży maturalnej $i$ akademickiej 5 maja 1968, w: tenże, Nie chciejcie łatwego życia, dz. cyt., s. 87.

35 Por. tamże, s. 83-87. 
leżności do rodziny, narodu czy Kościoła łączą ze sobą poszczególnych ludzi. Tym, co ich łączy, jest także wspólna wina, którą trzeba sobie uświadomić. Wyszyński przejmująco pisał o wspólnocie odpowiedzialności, jaka powinna tworzyć się pomiędzy ludźmi w odpowiedzi na wspólną winę: „Odpowiedzialność jest więc wspólna. Dlaczego? Bo wspólna jest i wina. Nikt z nas nie jest bez grzechu, nikt nie jest bez winy. Może się ona wyrażać w różnej formie. Może to być wina naruszenia osobowych praw ludzi, z czym wiąże się deformacja moralna i społeczna człowieka. Może to być wina wynikająca z braku obrony naszych praw, do czego jesteśmy zobowiązani, w miarę jak wypełniamy nasze obowiązki. Może to być brak świadomości społecznej, swoista bierność i niewrażliwość na dobro wspólne, społeczne, rodziny, Narodu i państwa. Niekiedy może brać górę troska o dobro osobiste czy zawodowe nad wartościami wyższego rzędu, jakimi są - dobro rodzin i dobro Narodu" ${ }^{36}$. Zamiast oskarżania innych, demaskowania ich słabości, Wyszyński proponuje wspólne dźwiganie winy. Człowiek, który uświadamia sobie, że sam nie jest pozbawiony winy, gotów będzie także dźwigać winę innych, wspólną winę. Dźwiganie winy prowadzić ma do ukształtowania się wspólnoty ludzi poszukujących trwałych i nienaruszalnych dóbr. Wśród tych dóbr Wyszyński wymienia wprost: porządek religijno-moralny, ład życia rodzinnego, porządek życia społeczno-zawodowego, ład życia narodowego ${ }^{37}$. Można powiedzieć, że w miejsce „gier o odpowiedzialność”, będących sposobem na pozbycie się winy, Wyszyński proponuje wspólne dźwiganie winy, umożliwiające poszukiwanie tego, co stanowić powinno fundament życia społecznego. Dramat winy staje się w ten sposób okazją do chronienia i promowania dobra, które rodzi się w spotkaniu ludzi należących do tego samego narodu i społeczeństwa.

\section{DUSZPASTERSKIE ROZWINIĘCIE FILOZOFII ODPOWIEDZIALNOŚCI}

Zestawienie Tischnerowskiej filozofii odpowiedzialności z tekstami poświęconymi temu zagadnieniu, jakie można odnaleźć w bogatym nauczaniu kardynała Wyszyńskiego, przynosi bardzo ciekawe rezultaty. Okazuje się, że w nauczaniu Wyszyńskiego odnaleźć można duszpasterskie rozwinięcie i ukonkretnienie analiz, które prowadzone są przez Tischnera na wyższym stopniu ogólności w ramach namysłu filozoficznego.

Dokonany przez Wyszyńskiego, bardzo szeroki i precyzyjny opis tożsamości człowieka, który podejmuje odpowiedzialność za mniej lub bardziej istotne sprawy własnego życia i życia innych ludzi, pokazuje, jak istotną kwestią jest właściwe

36 Tenże, Odpowiedzialność - Obowiazki - Prawa w życiu Narodu. Kazanie wygłoszone podczas sumy w uroczystość Matki Bożej Częstochowskiej Jasna Góra - 26 VIII 1980 r., w: Nauczanie społeczne Kardynała Stefana Wyszyńskiego (wybór tekstów), dz. cyt., s. 144.

37 Por. tamże, s. 145. 
zrozumienie siebie i swojego miejsca wobec Boga i wobec innych. Aby móc działać odpowiedzialnie, człowiek musi wiedzieć, „kim” jest i „po co” jest na tym świecie. Musi dokładnie znać swoje pochodzenie i cel swojego życia. Duszpasterskie rozwinięcie zagadnienia tożsamości umożliwia mocne zakorzenienie etycznej samoświadomości człowieka w prawdach wynikających z Objawienia. Częste nawiązywanie do tego zagadnienia w praktyce duszpasterskiej, przypominanie człowiekowi o jego tożsamości, pozwala mu skutecznie bronić się przed ideologiami, a także filozofiami, które proponują zawężone spojrzenie na człowieka.

Bardzo istotną rolę odgrywa także precyzyjne wskazywanie obowiązków, które pozostają w polu odpowiedzialności człowieka. Namysł kardynała Wyszyńskiego nad ,ppolami dla czynów płynących z miłości” jest bardzo precyzyjnym ukonkretnieniem tego, o czym pisał i co postulował ksiądz Józef Tischner. Jest rzeczą oczywistą, iż każde z tych pól jest niepowtarzalne, ponieważ niepowtarzalni są ludzie podejmujący odpowiedzialność za własne i cudze życie. Są jednak pewne elementy wspólne, których nazywanie i dookreślanie może pomóc człowiekowi odnaleźć własne pole odpowiedzialności. Wielość rozmaitych obowiązków, spraw do załatwienia oraz życiowych problemów sprawia, że trudno jest samemu precyzyjnie własne pole odpowiedzialności określić. Stąd bardzo przydatne jest nazywanie mogących wchodzić w grę obowiązków i kierowanie poszczególnych podpowiedzi w stronę konkretnych grup ludzi. Ważne jest jednak i to, by duszpasterskie dookreślanie pola odpowiedzialności miało charakter apelu, podpowiedzi, nie zaś nakazu czy niepodlegającego dyskusji polecenia. Apelując, nie tylko umożliwia się poszczególnym ludziom właściwe odczytanie ich zadań, lecz także, a może przede wszystkim, promuje niepowtarzalną godność każdego człowieka, która jest koniecznym warunkiem odpowiedzialności. Dookreślanie „pól odpowiedzialności” jawi się także jako sposób na wyznaczenie bardzo konkretnych zadań, które możliwe są do podjęcia i z których uczynić można program działania, a także z których można się przed Bogiem, samym sobą i innymi ludźmi rozliczyć.

Kolejnym z wątków jest precyzyjne dookreślenie winy, z jaką należy się zmierzyć. Wina, z którą próbowali się uporać ludzie w czasach, gdy Tischner pisał o „grach o odpowiedzialność”, nie była tą samą winą, jaką trzeba było podjąć w czasach, gdy o wspólnym jej dźwiganiu pisał Wyszyński. W obu przypadkach podjęta została jednak próba nazwania winy, z jaką trzeba się zmierzyć. Nazywanie winy po imieniu znacznie ułatwia wzięcie jej na swoje barki. Trudno bowiem dźwigać winę nieokreśloną. Przyjęcie winy miało stworzyć przestrzeń dla poszukiwania wspólnego dobra. W tekstach kardynała Wyszyńskiego odnajdujemy próby doprecyzowania tego, o jakie dobro chodzi. Nie tylko trudno jest dźwigać nienazwaną winę, lecz także trudno jest szukać nieokreślonego dobra. Wskazywanie rozmaitych konkretnych wymiarów tego dobra nie tylko ułatwia poszukiwanie, lecz także zwiększa motywację do angażowana się w poszukiwanie dobra. 


\section{PODSUMOWANIE}

Przeprowadzone w niniejszym tekście rozważania ukazały zbieżność myśli na temat odpowiedzialności, jakie znaleźć można w filozoficznych tekstach księdza Józefa Tischnera i mających duszpasterski charakter tekstach kardynała Stefana Wyszyńskiego oraz możliwość ukazania myśli tego drugiego jako rozwinięcia i dookreślenia idei i postulatów zawartych w tekstach pierwszego. Warto na koniec postawić pytanie o to, skąd wzięła się ta zbieżność i dlaczego możliwe było zinterpretowanie zaleceń duszpasterskich Wyszyńskiego jako mieszczących się na przedłużeniu filozoficznych analiz Tischnera. Sądzę, że odpowiedź mieści się w fakcie, iż obaj myśleli w odniesieniu do konkretnych ludzkich spraw. Obaj próbowali mierzyć się z tym samym międzyludzkim (i bosko-ludzkim) dramatem. Obaj także czerpali z etosu Ewangelii, która najpełniej pokazuje, gdzie bije źródło odpowiedzialności i jak jest możliwe wspólne dźwiganie winy. Dzięki spotkaniu myśli dwóch wielkich polskich nauczycieli chrześcijaństwa otrzymujemy nie tylko bardzo głębokie teoretyczne opracowanie zagadnienia odpowiedzialności, lecz także bardzo praktyczne podpowiedzi, jak wezwanie do odpowiedzialności realizować.

\section{Bibliografia}

Jagiełło J., Ingarden - Tischner. Od ontologii do agatologii odpowiedzialności, w: P. Duchliński (red.), Dziedzictwo etyki wspótczesnej. Aksjologia i etyka Romana Ingardena i jego uczniów. Studia i rozprawy, Wydawnictwo WAM, Kraków 2015, s. 241-268.

Przybyło S., Odpowiedzialność a wolność w myśli ks. Józefa Tischnera, w: Społeczeństwo odpowiedzialne? O aspektach odpowiedzialności w życiu społecznym jednostek, red. K. Cikała, W. B. Zieliński, Uniwersytet Papieski Jana Pawła II w Krakowie Wydawnictwo Naukowe, Kraków 2015, s. 7-17.

Tischner J., Etyka wartości i nadziei, w: J. Tischner, J. A. Kłoczowski, Wobec wartości, W drodze, Poznań 2001, s. 7-132.

Tischner J., Filozofia dramatu, Znak, Kraków 1999.

Tischner J., Gra wokół odpowiedzialności, „Znak” 485, 1995, s. 47-55.

Wajsprych D., Pedagogia agatologiczna. Studium hermeneutyczno-krytyczne projektu etycznego Józefa Tischnera, Wydawnictwo Naukowe Uniwersytetu Mikołaja Kopernika, Toruń-Olsztyn 2011.

Wojtyła K., Człowiek w polu odpowiedzialności, Instytut Jana Pawła II KUL, Rzym-Lublin 1991. 
Wyszyński S., Bogami jesteście. Do młodzieży akademickiej na zakończenie rekolekcji 17 marca 1973, w: S. Wyszyński, Nie chciejcie łatwego życia, Wydawnictwo UKSW, Warszawa 2007, s. 133-140.

Wyszyński S., Do rodziców katolickich w sprawie religijnego wychowania dzieci i młodzieży, w: Listy Pasterskie Prymasa Polski 1946-1974, Editions du Dialogue, Paris 1975, s. 207-211.

Wyszyński S., Do szkolnej młodzieży katolickiej z okazji nowego roku szkolnego, w: Listy Pasterskie Prymasa Polski 1946-1974, Editions du Dialogue, Paris 1975, s. 73-78.

Wyszyński S., Harmonia Bożo-ludzka w Polsce. II Kazanie wygłoszone w Bazylice Archikatedralnej Św. Jana Chrzciciela w Warszawie-6 I 1980 r., w: Nauczanie społeczne Kardynała Stefana Wyszyńskiego (wybór tekstów), Wydział Inicjatyw Społeczno-Katolickich Stowarzyszenia PAX, Warszawa 1983, s. 96-117.

Wyszyński S., Jakiej chcecie Polski? Do młodzieży akademickiej na zakończenie rekolekcji 22 marca 1972, w: S. Wyszyński, Nie chciejcie łatwego życia, Wydawnictwo UKSW, Warszawa 2007, s. 122-132.

Wyszyński S., List pasterski na Czwarty Tydzień Miłosierdzia, w: Listy Pasterskie Prymasa Polski 1946-1974, Editions du Dialogue, Paris 1975, s. 81-85.

Wyszyński S., List pasterski o społecznej krucjacie miłości, w: Listy Pasterskie Prymasa Polski 1946-1974, Editions du Dialogue, Paris 1975, s. 537-552.

Wyszyński S., List wielkopostny do duchowieństwa i wiernych Archidiecezji gnieźnieńskiej i warszawskiej, w: Listy Pasterskie Prymasa Polski 1946-1974, Editions du Dialogue, Paris 1975, s. 613-619.

Wyszyński S., Na siódmy rok Wielkiej Nowenny, w: Listy Pasterskie Prymasa Polski 1946-1974, Editions du Dialogue, Paris 1975, s. 424-427.

Wyszyński S., Odpowiedzialność-Obowiązki-Prawa w życiu Narodu. Kazanie wygłoszone podczas sumy w uroczystość Matki Bożej Częstochowskiej. Jasna Góra-26 VIII 1980 r., w: Nauczanie społeczne Kardynała Stefana Wyszyńskiego (wybór tekstów), Wydział Inicjatyw Społeczno-Katolickich Stowarzyszenia PAX, Warszawa 1983, s. 141-157.

Wyszyński S., O katolickiej woli życia, w: Listy Pasterskie Prymasa Polski 1946-1974, Editions du Dialogue, Paris: 1975, s. 50-63.

Wyszyński S., Wasza godność i czas cenniejsze niż złoto. Inauguracja roku akademickiego 4 października 1970, w: S. Wyszyński, Nie chciejcie łatwego życia, Wydawnictwo UKSW, Warszawa 2007, s. 113-121.

Wyszyński S., Wiara i odpowiedzialność, Wydawnictwo Sumus, Soli Deo, Zielonka 2021.

Wyszyński S., Wspólnota ludzka. Konferencja na temat Konstytucji duszpasterskiej o Kościele w świecie współczesnym. 4 marca 1968, w: Nie chciejcie tatwego życia, Wydawnictwo UKSW, Warszawa 2007, s. 384-401. 
Wyszyński S., Wyzwolenie z niewoli nienawiści przez niewolę miłości. Do młodzieży maturalnej i akademickiej 5 maja 1968, w: S. Wyszyński, Nie chciejcie tatwego życia, Wydawnictwo UKSW, Warszawa 2007, s. 81-92.

Wyszyński S., Zachęta do duchowieństwa $i$ wiernych na Wielki Post, w: Listy Pasterskie Prymasa Polski 1946-1974, Editions du Dialogue, Paris 1975, s. 223-226.

Wyszyński S., Zapiski więzienne, Editions du Dialogue, Paris 1982. 